\title{
Genetic variation of indigenous, improved and exotic allium sativum germplasm
}

\begin{abstract}
The present experiment was conducted at the Horticulture Farm of the Bangladesh Agricultural University, Mymensingh during the period from November, 2010 to April, 2011 to study the field performance and genetic variation of different germplasm of garlic. The experiment was carried out with 25 garlic germplasm, which were collected from different parts of Bangladesh, Tunisia, Turkey, Florida, China and Vietnam. Results review that all the treatments vary significantly among themselves regarding plant height, number of leaves, length of leaves, fresh weight of leaves, fresh weight of root, fresh weight of bulb, dry weight of leaves, dry weight of root, dry weight of bulb, diameter of bulb, number of cloves and yield of bulb per hectare. The relationship among the different variables especially with yield was done by Pearson's correlation and multiple regression analyses. Different qualitative characteristics of 25 garlic germplasm namely color of leaf, shape of leaf, color of bulb, shape of bulb, predominant bulb scale and secondary clove skin color were also studied. The correlation analysis revealed that the yield of bulb per hectare is significantly correlated with length of leaves and number of cloves per bulb. From the study of heritability on broad sense, it was very high in height of plant, length of leaves, fresh weight of leaves, yield of bulb, fresh weight of root, dry weight of root and number of cloves per bulb. The genotypic and phenotypic variances were found to be low and moderate among the germplasm. The difference between Genoptypic co-efficient of variance (GCV) and Phenotypic co-efficient of variance (PCV) were very low in relation to height of plant and fresh weight of leaves; moderate in number of leaves per plant and other parameters.
\end{abstract}

Keywords: garlic germplasm, genetic variation, heritability, genoptypic co-efficient of variance, phenotypic co-efficient of variance
Volume I Issue 2 - 2014

\author{
Mahfuza Pervin,' Md Kamrul Hassanm, ${ }^{2}$ \\ Kamrul Hassan, ${ }^{3}$ AKM A Hoque ${ }^{4}$ \\ 'Bangladesh Institute of Nuclear Agriculture (BINA), Bangladesh \\ ${ }^{2}$ Department of Horticulture, Bangladesh Agricultural University, \\ Bangladesh \\ ${ }^{3}$ Department of Entomology, Sylhet Agricultural University, \\ Bangladesh \\ ${ }^{4}$ Bangladesh Agricultural Research Institute (BARI), Bangladesh
}

Correspondence: Kamrul Hassan, Department of Entomology, Sylhet Agricultural University, Sylhet-3 100, Bangladesh, Email: shishir244@gmail.com

Received: May 03, 2014 | Published: July 04, 2014
Abbreviations: GCV, genoptypic co-efficient of variance; PCV, phenotypic co-efficient of variance; AEZ, agro ecological zone; RCBD, randomized complete block design

\section{Introduction}

Garlic is a thermo and photo-sensitive crop, and its vegetative growth and bulb development are greatly influenced by growing environment. ${ }^{1,2}$ In Bangladesh, the production of garlic is confined to the relatively short, cool winter season following which the onset of rapidly rising temperatures is associated with adverse bulb development and maturation. Variability is a desirable goal in germplasm collection, since the materials conserved in such a collection represent the stock material for breeding programme. ${ }^{3}$ Hence, the knowledge of the interrelationships among and between yields and yield components is necessary; determination of correlation between vegetative characteristics is a matter of considerable importance in selection of correlated responses. Following correlation analysis, the path-co-efficient analysis would provide a true picture of genetic association among different traits. ${ }^{4}$ Path-co-efficient analysis helps to specify the cause and effect and to measure their relative significance. So, correlation in combination with the path-co-efficient analysis quantifies the direct and indirect contributions of one characteristic upon another. ${ }^{5}$ In crop improvement programme, genetic diversity ${ }^{6}$ has been considered as an important factor and an essential tool for hybridization programme. For planning and execution of genetic improvement programme a clear understanding of the magnitudes of genetic diversities for yield and its component characteristics are important to plant breeders for both cross and self pollinated crops. ${ }^{7}$ Selection of genetically diverse parents for a successful hybridization programme is now possible through biometric procedure, which helps in quantification of genetic diversity.

There is a wide range of possible study objectives that can be served by genetic tools, including:

- Determining whether plants have hybridized

- Deciding on appropriate (source) plant materials for restoration

- Determining the ploidy level of certain plants or populations

- Monitoring changes in Genetic diversity over time

- Identifying plants as belonging to the same or different clone or population and so on.

\section{Materials and methods}

The experiment was conducted at the field of USDA Alliums Project of the BAU Germplasm Centre, Department of Horticulture, Bangladesh Agricultural University, Mymensingh, during the period from November, 2010 to April, 2011. The soil of the experimental field belongs to Agro ecological zone (AEZ) 8 and 9, which is characterized by flood free highland, fine in texture (sandy loam to loamy), poor in organic matter $(1.1 \%)$. The total rainfall of the locality during the crop growing period was $2.75 \mathrm{~mm}$ only. The daily 
evaporation during the growing season ranges from 0.84 to $2.87 \mathrm{~mm}$. The average maximum air temperature lies between $22.6^{\circ} \mathrm{C}$ and $31.4^{\circ} \mathrm{C}$ and minimum air temperature between $11.5^{\circ} \mathrm{C}$ and $23.7^{\circ} \mathrm{C}$ during the experimentation. The daily average relative humidity during season was mostly between 45 to $90 \%$. For the research work, 25 germplasm of garlic were collected from different regions of the world. Different qualitative characters ${ }^{10}$ of 25 garlic germplasm namely color of leaves, shape of leaves, color of bulb, shape of bulb, predominant bulb scale leaf color and secondary clove skin color were evaluated. The germplasm used as treatments were BAU 1, BAU 2 , G3, G5, G8, G10, G13, G15, G19, G20, G27, G28, G29, G30, G31, G32, G33, G35, G36, G37, G38, G49, G51, G52 and G53. Among the germplasm 15 were collected from Bangladesh, 2 from Florida, 3 from Tunisia, 2 from Turkey, 1 from China and 2 from Vietnam. The single factor experiment was laid out in randomized complete block design $(\mathrm{RCBD})^{11}$ with three replications. Initially the whole experimental area was divided into three blocks each of which was then divided into 25 unit plots to represent the 25 treatments into three replications. Relation of variables with the yield was studied using Pearson's Correlation Co-efficient and Multiple Regression analysis.

\section{Results and discussion}

\section{Qualitative characters of garlic germplasm}

Leaf color varied from light green to dark green among different germplasm. The shape of leaves of 25 germplasm was cylindrical. Bulbs varied from globular to elongated shape. Predominant bulb scale leaf color varied from radish white to white in color. Correlation co-efficient analysis was performed to estimate the mutual relationship between yield and yield contributing characters on which selection could be based for further improvement of garlic. ${ }^{12}$

\section{Relation among different characters of garlic germplasm with yield}

Plant height showed significant positive correlation with number of leaves $(\mathrm{r}=0.366)$, fresh weight of bulb $(\mathrm{r}=0.307)$ and dry weight of bulb $(\mathrm{r}=0.325)$. Relationships were positive, for the characters like length of leaf, fresh weight of leaves, dry weight of leaves, fresh weight of roots, dry weight of roots, diameter of bulb, number of cloves per bulb and yield of bulb (Table 1). Number of leaves per plant was found significantly correlated with plant height $(\mathrm{r}=0.366)$, dry weight of leaves $(r=0.337)$, fresh weight of roots $(r=0.283)$ and dry weight of bulb $(r=0.234)$. Positive correlation was found with length of leaf $(\mathrm{r}=0.126)$, fresh weight of leaves $(\mathrm{r}=0.100)$, fresh weight of bulb $(r=0.177)$, diameter of bulb $(r=0.029)$, number of cloves per bulb $(r=0.093)$ and yield of bulb $(r=0.029)$. Length of leaf showed good, positive and significant correlation with fresh weight of bulb $(\mathrm{r}=0.415)$, dry weight of bulb $(\mathrm{r}=0.463)$ and diameter of bulb $(\mathrm{r}=0.348)$. Positive correlation with fresh weight of leaves $(\mathrm{r}=0.083)$, dry weight of leaves $(\mathrm{r}=0.163)$, number of cloves per bulb $(\mathrm{r}=0.007)$, yield of bulb $(r=0.132)$. Fresh weight of leaves showed good, positive and significant correlation with dry weight of leaves $(\mathrm{r}=0.586)$, fresh weight of roots $(r=0.354)$, fresh weight of bulb $(r=0.407)$, dry weight of bulb ( $\mathrm{r}=0.374)$ and diameter of bulb $(\mathrm{r}=0.409)$, positive correlation with length of leaf $(r=0.083)$ and dry weight of root $(r=0.201)$. Fresh weight of leaves showed negative but insignificant relationship with number of cloves per bulb $(\mathrm{r}=-0.044)$. Dry weight of leaves showed good, positive and significant correlation with fresh weight of leaves $(r=0.586)$, fresh weight of roots $(r=0.396)$, fresh weight of bulb $(r=0.246)$ and dry weight of bulb $(r=0.281)$. Positive correlation with length of leaf $(r=0.163)$ and dry weight of roots $(r=0.188)$. Dry weight of leaves showed negative but insignificant relationship with number of cloves per bulb $(\mathrm{r}=-0.082)$ and yield of bulb $(\mathrm{r}=-$ 0.196) (Table 1). Fresh weight of bulb showed good, positive and significant correlation with length of leaf $(\mathrm{r}=0.415)$, fresh weight of leaves $(\mathrm{r}=0.407)$, dry weight of leaves $(\mathrm{r}=0.246)$, dry weight of bulb $(r=0.950)$ and diameter of bulb $(r=0.741)$. Positive correlation with fresh weight of roots $(\mathrm{r}=0.128)$ and dry weight of roots $(\mathrm{r}=0.113)$. Fresh weight of bulb showed negative but insignificant relationship with yield of bulb $(r=-0.141)$. Fresh weight of bulb showed negative but significant relationship with number of cloves per bulb ( $\mathrm{r}=-0.304)$. Dry weight of bulb showed positive and significant relationship with length of leaf $(\mathrm{r}=0.463)$, fresh weight of leaves $(\mathrm{r}=0.374)$, dry weight of leaves $(r=0.281)$, fresh weight of bulb $(r=0.950)$ and diameter of bulb $(\mathrm{r}=0.734)$. Positive correlation with fresh weight of roots $(\mathrm{r}=0.096)$. Dry weight of bulb showed negative but insignificant relationship with yield of bulb $(\mathrm{r}=-0.079)$. Dry weight of bulb showed negative but significant relationship with number of cloves. Per bulb $(\mathrm{r}=-0.320)$ (Table 1). The correlation $\left(\mathrm{R}^{2}=0.0069\right)$ and regression equation $y=0.0464 x+5.1053$. The relationship was evident with line of regression of total yield on dry weight of bulb. Fresh weight of roots showed good, positive and significant correlation with fresh weight of leaves $(r=0.354)$, dry weight of leaves $(r=0.396)$ and dry weight of roots $(\mathrm{r}=0.335)$. Positive correlation with fresh weight of bulb $(\mathrm{r}=0.128)$, dry weight of bulb $(\mathrm{r}=0.096)$ and diameter of bulb $(r=0.023)$. Fresh weight of roots showed negative but insignificant relationship with length of leaf $(\mathrm{r}=-0.201)$. It showed negative but significant relationship with number of cloves per bulb $(\mathrm{r}=-0.363)$ and yield of bulb $(\mathrm{r}=-0.314)$. The correlation $\left(\mathrm{R}^{2}=0.1328\right)$ and regression equation $y=0.71916 x+7.1614$. The relationship was evident with line of regression of total yield on fresh weight of roots. Dry weight of roots showed good, positive and significant correlation with fresh root weight $(r=0.335)$. Positive correlation with fresh leaf weight $(\mathrm{r}=0.201)$, dry weight of leaves $(\mathrm{r}=0.188)$, fresh weight of bulb $(r=0.113)$ and diameter of bulb $(r=0.049)$. Dry weight of roots showed negative but insignificant relationship with length of leaf $(\mathrm{r}=-$ $0.128)$, dry weight of bulb $(\mathrm{r}=-0.014)$ and yield of bulb $(\mathrm{r}=-0.034)$. Dry weight of roots showed negative but significant relationship with number of cloves per bulb $(\mathrm{r}=-0.242)$ (Table 1). Diameter of bulb showed highly significant and positive correlation with length of leaf $(\mathrm{r}=0.348)$, fresh weight of leaves $(\mathrm{r}=0.409)$, fresh weight of bulb $(r=0.741)$, dry weight of bulb $(r=0.734)$ and dry weight of leaves $(r=0.254)$. Diameter of bulb showed positive correlation with fresh weight of roots $(\mathrm{r}=0.023)$ and dry weight of roots $(\mathrm{r}=0.049)$. Diameter of bulb showed negative but insignificant relationship with number of cloves per bulb $(\mathrm{r}=-0.151)$. Diameter of bulb showed negative but significant relationship with yield of bulb $(\mathrm{r}=-0.299)$ (Table 2$)$. The correlation $\left(\mathrm{R}^{2}=0.117\right)$ and regression equation $\mathrm{y}=-2.031 \mathrm{x}+11.18$. The relationship was evident with line of regression of total yield on diameter of bulb. Number of cloves per plant showed positive and significant relationship with yield of bulb $(r=0.213)$ and length of leaf $(\mathrm{r}=0.007)$. Number of cloves per plant showed negative but significant relationship with fresh weight of roots $(\mathrm{r}=-0.363)$, dry weight of roots $(\mathrm{r}=-0.242)$, fresh weight of bulb $(\mathrm{r}=-0.304)$ and dry weight of bulb $(\mathrm{r}=-$ 0.320 ). Number of cloves per plant showed negative but insignificant relationship with fresh weight of leaves $(\mathrm{r}=-0.044)$, dry weight of leaves $(\mathrm{r}=-0.082)$ and diameter of bulb $(\mathrm{r}=-0.151)$. Yield of bulb per hectare showed little, positive and significant correlation with length of leaf $(r=0.132)$ and number of cloves per bulb $(r=0.213)$. Yield of bulbs per hectare showed negative but insignificant relationship with dry leaf weight ( $r=-0.196)$, dry root weight $(r=-0.034)$, fresh weight of bulb $(r=-0.141)$ and dry weight of bulb $(r=-0.079)$. Yield of bulb per hectare showed negative but significant relationship with fresh weight of leaves $(r=-0.300)$, fresh weight of roots $(r=-0.314)$ and diameter of 
root $(r=-0.299)$ (Table 1$)$. In the highest yielding germplasm has the number of cloves per bulb is high. It can be because organic manures used kept the soil loose and helps in supply of adequate plant nutrients for better vegetative growth of garlic plants and ultimately increased bulb diameter.

Table I Correlation (pearson's correlations) among yield and yield contributing characters

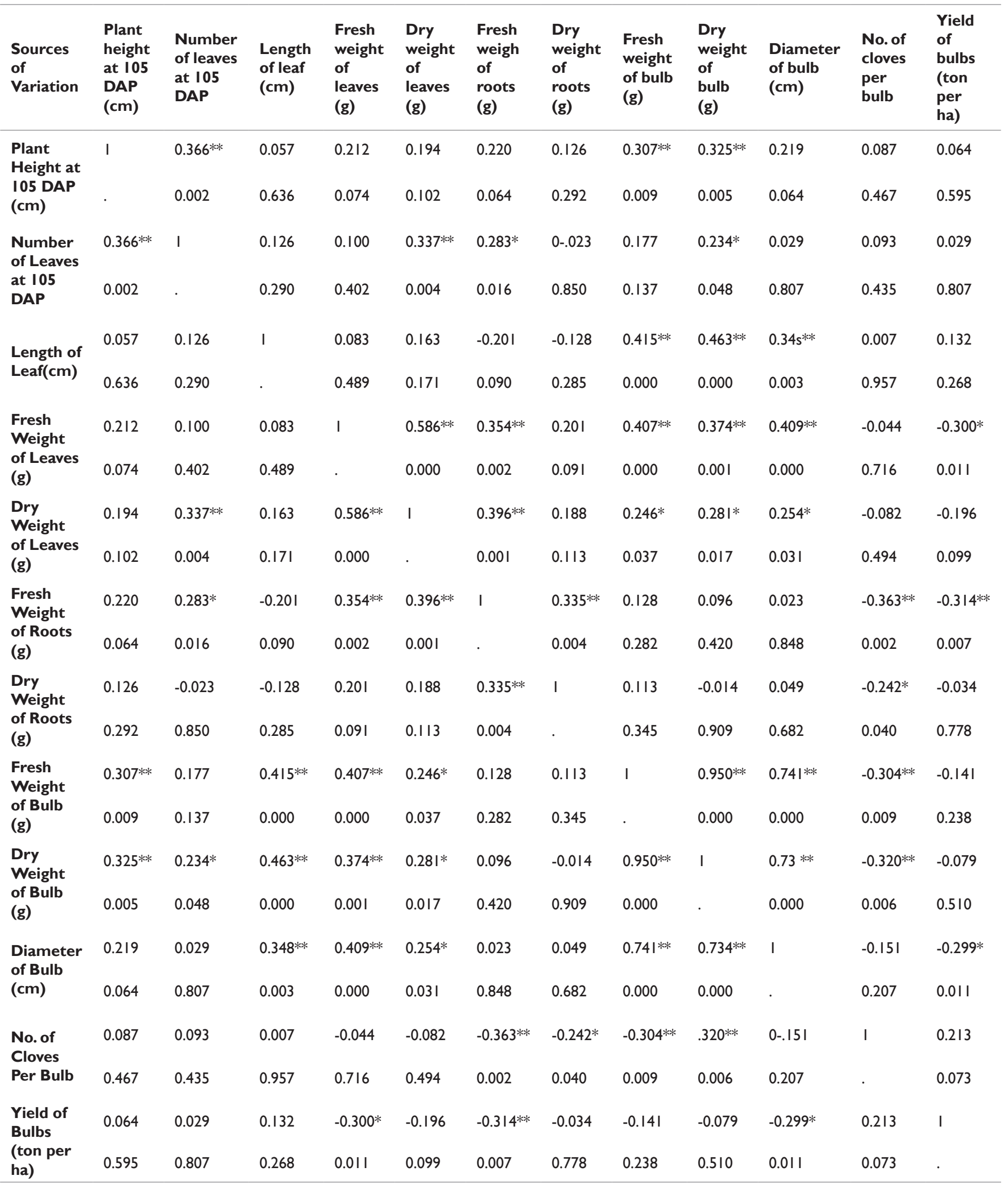

*Correlation is significant at the 0.05 level (2-tailed)

**Correlation is significant at the 0.01 level (2-tailed)

Citation: Pervin M, Kamrul Hassan Md, Hassan K, et al. Genetic variation of indigenous, improved and exotic allium sativum germplasm. Adv Plants Agric Res. 20I4; I(2):54-60. DOI: I0.15406/apar.20I4.0I.000II 


\section{Genetic variation with heritability studies of garlic germplasm}

The genotypic and phenotypic variances of plant height were 32.39 and 32.67 , respectively. The difference between genotypic co-efficient of variance (GCV) $(11.77 \%)$ and phenotypic co-efficient of variance $(11.82 \%)$ was low which indicates less influence of environment on the performance of particular trait. Heritability in broad sense (H2b) was calculated also and it was $99.16 \%$, which was very high (Table 2). ${ }^{13}$ The genotypic and phenotypic variances of number of leaves were 0.45 and 0.75 respectively. Genotypic co-efficient of variance (GCV) was lower than phenotypic co-efficient of variance $(10.83$ and $14.07 \%$, respectively), which indicated larger influences of environment on the performance of particular trait. The heritability in broad sense (H2b) for this trait was very low $59.27 \%$ (Table 3 ). The genotypic and phenotypic variances of length of leaf were 24.72 and 25.39 respectively. Difference between GCV (13.82\%) and PCV $(14.00 \%)$ was low which indicates less influence of environment on the performance of particular trait that the trait was genetically controlled. The heritability in broad sense (H2b) for this trait was very high $97.37 \%$. The genotypic and phenotypic variances of fresh weight of leaves were 519.55 and 519.85 respectively. The difference between genotypic co-efficient of variance (GCV) $(57.82 \%)$ and phenotypic co-efficient of variance $(57.84 \%)$ was very low which indicates less influence of environment on the performance of particular trait and the trait was genetically controlled. Heritability in broad sense (H2b) was calculated also and it was (99.94\%), which was very high (Table 2). The genotypic and phenotypic variances of dry weight of leaves were 1.73 and 1.86 respectively. Moderate difference between GCV (31.40\%) and PCV (32.60\%) was low which indicates less influence of environment on the performance of particular trait The heritability in broad sense (H2b) for this trait was very high $92.75 \%$ (Table 2). The genotypic and phenotypic variances of fresh weight of roots were 0.50 and 0.58 respectively. Moderate difference between GCV (19.03\%) and PCV (20.38\%) was low which indicates less influence of environment on the performance of particular trait. The heritability in broad sense ( $\mathrm{H} 2 \mathrm{~b}$ ) for this trait was moderately high $87.21 \%$ (Table 3 ). The genotypic and phenotypic variances of dry weight of roots were 0.15 and 0.19 respectively. Genotypic coefficient of variance $(\mathrm{GCV})$ was lower than phenotypic co-efficient of variance (39.30 and $43.41 \%$, respectively) which indicated larger influences of environment on the performance of particular trait. The heritability in broad sense (H2b) for this trait was moderately high $81.95 \%$. The genotypic and phenotypic variances of fresh weight of bulb were 6.72 and 7.29 respectively. Moderate difference between GCV (17.43\%) and PCV (18.15\%) was low which indicates less influence of environment on the performance of particular trait. The heritability in broad sense (H2b) for this trait was very high $92.24 \%$ (Table 2). The genotypic and phenotypic variances of dry weight of bulb were 5.81 and 6.22 respectively. Moderate difference between GCV (17.78\%) and PCV (18.40\%) was low which indicates less influence of environment on the performance of particular trait. The heritability in broad sense (H2b) for this trait was very high $93.41 \%$. The genotypic and phenotypic variances of diameter of bulb were 0.04 and 0.08 respectively. Genotypic co-efficient of variance (GCV) was lower than phenotypic co-efficient of variance (6.30 and 8.37 $\%$, respectively) which indicated larger influences of environment on the performance of particular trait. The heritability in broad sense (H2b) for this trait was very low $56.77 \%$. The genotypic and phenotypic variances of number of cloves per bulb were 10.49 and
12.07 respectively. Genotypic co-efficient of variance (GCV) was lower than phenotypic co-efficient of variance (14.86 and $15.94 \%$, respectively) which indicated moderate influences of environment on the performance of particular trait. The heritability in broad sense (H2b) for this trait was moderately high 86.94. The genotypic and phenotypic variances of yield of bulb were 1.87 and 1.94 respectively. Moderate difference between GCV (30.58\%) and PCV (31.15\%) was low which indicates less influence of environment on the performance of particular trait. The heritability in broad sense (H2b) for this trait was very high $96.40 \%$ (Table 2 ).

\section{Path co-efficient analysis of garlic germplasm}

In order to find clear interrelationships among the yield and yield contributing characteristics, direct and indirect effects were worked out using path co-efficient analysis. From the result of path co-efficient analysis, it was revealed that plant height had positive effect (0.062) on the yield per plant. It showed positive effect on length of leaf, dry weight of leaves, dry weight of roots, dry weight of bulb and number of cloves per bulb. Oppositely, it showed negative effect on number of leaves, fresh weight of leaves, fresh weight of roots, fresh weight of bulb and diameter of bulb. Number of leaves exhibited positive effect $(0.012)$ on the yield per plant. It showed positive effect on yield via height of plant, length of leaf, dry weight of leaves, fresh weight of roots, dry weight of roots and diameter of bulb. On the other hand, it showed negative effect on number of leaves, fresh weight of leaves, fresh weight of bulb dry weight of bulb and number of cloves per bulb (Table 3). Length of leaf exhibited positive effect (0.136) on the yield per plant. It showed positive effect on yield via height of plant, length of leaf, dry weight of leaves, dry weight of bulb, diameter of bulb and number of cloves per bulb. On the counter part, it showed negative effect on fresh weight of leaves, fresh weight of roots and dry weight of roots. Fresh weight of leaves had direct negative effect (-0.316) on the yield per plant. It showed positive effect on height of plant, length of leaf, dry weight of leaves, dry weight of roots and dry weight of bulb. Oppositely, it showed negative effect on number of leaves, fresh weight of leaves, fresh weight of roots, fresh weight of bulb, diameter of bulb and number of cloves per bulb (Table 3 ). Dry weight of leaves had direct negative effect $(-0.209)$ on the yield per plant. It showed positive effect on height of plant, length of leaf, dry weight of roots and dry weight of bulbs. On the counter part, it showed negative effect on fresh weight of leaves, fresh weight of roots, fresh weight of bulb, diameter of bulb and number of cloves per bulb. Fresh weight of roots had direct negative effect $(-0.364)$ on the yield per plant. It showed positive effect on height of plant, dry weight of roots and dry weight of bulb. On the counter part, it showed negative effect on length of leaf, fresh weight of leaves, fresh weight of roots, fresh weight of bulb, dry weight of leaves, diameter of bulb and number of cloves per bulb. Fresh weight of bulb had direct negative effect (-0.148) on the yield per plant. It showed positive effect on height of plant, length of leaf dry weight of leaves, dry weight of roots and dry weight of bulb. On the counter part, it showed negative effect on fresh weight of leaves, fresh weight of roots, fresh weight of bulb, diameter of bulb and number of cloves per bulb. Dry weight of roots had direct negative effect $(-0.031)$ on the yield per plant. It showed positive effect on height of plant, length of leaf, dry weight of leaves, dry weight of roots and dry weight of bulb. Oppositely, it showed negative effect on number of leaves, fresh weight of leaves, fresh weight of roots, fresh weight of bulb, diameter of bulb and number of cloves per bulb. Dry weight of bulb had direct negative effect $(-0.091)$ on the yield per 
plant. It showed positive effect on height of plant, length of leaf, dry weight of roots and dry weight of bulb. On the counter part, it showed negative effect on length of leaves, fresh weight of leaves, fresh weight of roots, fresh weight of bulb, dry weight of leaves, diameter of bulb and number of cloves per bulb. Diameter of bulbs had direct negative effect $(-0.343)$ on the yield per plant. It showed positive effect on height of plant, number of leaves, length of leaf, dry weight of leaves, dry weight of roots and dry weight of bulb. Oppositely, it showed negative effect on fresh weight of leaves, fresh weight of roots, fresh weight of bulb, diameter of bulb and number of cloves per bulb. Number of cloves exhibited positive effect $(0.223)$ on the yield per plant. It showed positive effect on yield via height of plant fresh weight of leaves, fresh weight of roots and diameter of bulb. On the counter part, it showed negative effect on length of leaf, dry weight of roots, dry weight of leaves and dry weight of bulb (Table 3).

Table 2 Estimation of genetic parameters in respect of yields and yield contributing characters of the 25 garlic germplasm

\begin{tabular}{|c|c|c|c|c|c|c|c|c|c|c|c|c|}
\hline $\begin{array}{l}\text { Sources of } \\
\text { Variation }\end{array}$ & $\begin{array}{l}\text { Height } \\
\text { of the } \\
\text { plant at } \\
\text { I } 05 \text { DAP } \\
(\mathrm{cm})\end{array}$ & $\begin{array}{l}\text { No. of } \\
\text { leaves } \\
\text { at I05 } \\
\text { DAP }\end{array}$ & $\begin{array}{l}\text { Length } \\
\text { of leaf } \\
(\mathrm{cm})\end{array}$ & $\begin{array}{l}\text { Fresh } \\
\text { weight } \\
\text { of } \\
\text { leaves } \\
\text { (g) }\end{array}$ & $\begin{array}{l}\text { Dry } \\
\text { weight } \\
\text { of } \\
\text { leaves } \\
\text { (g) }\end{array}$ & $\begin{array}{l}\text { Fresh } \\
\text { weight } \\
\text { of } \\
\text { roots } \\
\text { (g) }\end{array}$ & $\begin{array}{l}\text { Dry } \\
\text { weight } \\
\text { of } \\
\text { roots } \\
\text { (g) }\end{array}$ & $\begin{array}{l}\text { Fresh } \\
\text { weight } \\
\text { of } \\
\text { bulb } \\
\text { (g) }\end{array}$ & $\begin{array}{l}\text { Dry } \\
\text { weight } \\
\text { of } \\
\text { bulb } \\
\text { (g) }\end{array}$ & $\begin{array}{l}\text { Diameter } \\
\text { of bulb } \\
(\mathrm{cm})\end{array}$ & $\begin{array}{l}\text { No. of } \\
\text { cloves } \\
\text { per } \\
\text { bulb }\end{array}$ & $\begin{array}{l}\text { Yield } \\
\text { of } \\
\text { bulbs } \\
\text { (ton } \\
\text { per } \\
\text { ha) }\end{array}$ \\
\hline $\begin{array}{l}\text { Genotypic } \\
\text { Variance }\end{array}$ & 32.39 & 0.45 & 24.72 & 519.55 & 1.73 & 0.50 & 0.15 & 6.72 & 5.81 & 0.04 & 10.49 & 1.87 \\
\hline $\begin{array}{l}\text { Phenotypic } \\
\text { Variance }\end{array}$ & 32.67 & 0.75 & 25.39 & 519.85 & 1.86 & 0.58 & 0.19 & 7.29 & 6.22 & 0.08 & 12.07 & 1.94 \\
\hline $\begin{array}{l}\text { Genotypic } \\
\text { Co- } \\
\text { efficient of } \\
\text { Variation } \\
\text { (\%) }\end{array}$ & II.77 & 10.83 & 13.82 & 57.82 & 31.40 & 19.03 & 39.30 & 17.43 & 17.78 & 6.30 & 14.86 & 30.58 \\
\hline $\begin{array}{l}\text { Phenotypic } \\
\text { Co- } \\
\text { efficient of } \\
\text { Variation } \\
(\%)\end{array}$ & 11.82 & 14.07 & 14.00 & 57.84 & 32.60 & 20.38 & 43.41 & 18.15 & 18.40 & 8.37 & 15.94 & 31.15 \\
\hline $\begin{array}{l}\text { Heritability } \\
\text { in Broad } \\
\text { Sense }\left(h^{2} b\right)\end{array}$ & 99.16 & 59.27 & 97.37 & 99.94 & 92.75 & 87.21 & 81.95 & 92.24 & 93.41 & 56.77 & 86.94 & 96.40 \\
\hline GA & 11.68 & 1.06 & 10.11 & 46.94 & 2.61 & 1.37 & 0.73 & 5.13 & 4.80 & 0.32 & 6.22 & 2.77 \\
\hline GA\% & 24.15 & 17.18 & 28.09 & 119.08 & 62.30 & 36.61 & 73.29 & 34.49 & 35.40 & 9.78 & 28.54 & 61.85 \\
\hline Range & $\begin{array}{l}36.07- \\
58.47\end{array}$ & $\begin{array}{l}4.33- \\
7.33\end{array}$ & $\begin{array}{l}22.48- \\
42.82\end{array}$ & $\begin{array}{l}19.19- \\
90.57\end{array}$ & $\begin{array}{l}6.14- \\
104.67\end{array}$ & $\begin{array}{l}2.45- \\
5.40\end{array}$ & $\begin{array}{l}0.19- \\
1.59\end{array}$ & $\begin{array}{l}12.50- \\
23.13\end{array}$ & $\begin{array}{l}10.93- \\
21.37\end{array}$ & $3.04-3.88$ & $\begin{array}{l}13.0- \\
26.67\end{array}$ & $\begin{array}{l}1.85- \\
7.79\end{array}$ \\
\hline Mean士SE & $\begin{array}{l}48.34 \\
\pm I .14\end{array}$ & $\begin{array}{l}6.16 \\
\pm 0.15\end{array}$ & $\begin{array}{l}35.98 \\
\pm 1.00\end{array}$ & $\begin{array}{l}39.42 \\
\pm 4.56\end{array}$ & $\begin{array}{l}4.19 \\
\pm 0.26\end{array}$ & $\begin{array}{l}3.73 \\
\pm 0.14\end{array}$ & $\begin{array}{l}1.00 \\
\pm 0.08\end{array}$ & $\begin{array}{l}14.87 \\
\pm 0.53\end{array}$ & $\begin{array}{l}13.55 \\
\pm 0.49\end{array}$ & $\begin{array}{l}3.30 \\
\pm 0.05\end{array}$ & $\begin{array}{l}21.80 \\
\pm 0.66\end{array}$ & $\begin{array}{l}4.48 \\
\pm 0.28\end{array}$ \\
\hline
\end{tabular}

GA, genetic advance; SE, standard error 
Table 3 Path co-efficient analysis (phenotypic) showing direct and indirect effects on yield component of the 25 garlic germplasm

\begin{tabular}{|c|c|c|c|c|c|c|c|c|c|c|c|c|}
\hline $\begin{array}{l}\text { Sources } \\
\text { of } \\
\text { Variation }\end{array}$ & $\begin{array}{l}\text { Height } \\
\text { of the } \\
\text { plant at } \\
\text { different } \\
\text { I05 } \\
\text { DAP } \\
(\mathrm{cm})\end{array}$ & $\begin{array}{l}\text { No. of } \\
\text { leaves at } \\
\text { different } \\
105 \\
\text { DAP }\end{array}$ & $\begin{array}{l}\text { Length } \\
\text { of leaf } \\
(\mathrm{cm})\end{array}$ & $\begin{array}{l}\text { Fresh } \\
\text { weight } \\
\text { of } \\
\text { leaves } \\
\text { (g) }\end{array}$ & $\begin{array}{l}\text { Dry } \\
\text { weight } \\
\text { of } \\
\text { leaves } \\
\text { (g) }\end{array}$ & $\begin{array}{l}\text { Fresh } \\
\text { weight } \\
\text { of } \\
\text { root } \\
\text { (g) }\end{array}$ & $\begin{array}{l}\text { Dry } \\
\text { weight } \\
\text { of } \\
\text { roots } \\
\text { (g) }\end{array}$ & $\begin{array}{l}\text { Fresh } \\
\text { weight } \\
\text { of } \\
\text { bulb } \\
\text { (g) }\end{array}$ & $\begin{array}{l}\text { Dry } \\
\text { weight } \\
\text { of } \\
\text { bulb } \\
\text { (g) }\end{array}$ & $\begin{array}{l}\text { Diameter } \\
\text { of bulb } \\
(\mathrm{cm})\end{array}$ & $\begin{array}{l}\text { No. of } \\
\text { cloves } \\
\text { Per } \\
\text { Bulb }\end{array}$ & $\begin{array}{l}\text { Yield of } \\
\text { bulbs } \\
\text { (ton } \\
\text { per ha) }\end{array}$ \\
\hline
\end{tabular}

Height

of the

Plant at

Different

$-0.12$

0.0025

$\begin{array}{llll}-0.011 & 0.0094 & -0.079 & 0.042\end{array}$

$-0.204 \quad 0.517$

$-0.313$

0.025

0.062

(cm)

No. of

Leaves at

Different

$-0.287$

0.0076

$-0.0073$

0.019

$-0.130$

$\begin{array}{lll}-0.0076 & -0.119 & 0.395\end{array}$

0.0197

0.035

0.012

105 DAP

Length

of Lea

0.0036

$-0.0161$

0.13

$-0.0048$

$\begin{array}{lll}0.0048 & 0.0096 & 0.065\end{array}$

$-0.024$

$-0.289$

0.746

$-0.481 \quad 0.136$

Fresh

Weight

of Leaves

$0.040 \quad-0.038$

0.012

$-0.055$

0.030

$-0.138 \quad 0.064$

$-0.277$

0.617

$-0.554$

$-0.163-0.316^{*}$

(g)

Dry

Weight

of Leaves

$0.037-0.109$

0.026

$-0.033$

0.050

$-0.161 \quad 0.067$

$\begin{array}{lll}-0.177 & 0.486 & -0.365\end{array}$

$\begin{array}{ll}-0.030 & -0.209\end{array}$

(g)

Fresh

Weight

of Roots

0.04

$-0.106$

$-0.025$

$-0.022-0.023$

$-0.35$

0.112

$-0.096$

$0.191 \quad-0.021$

$-0.111 \quad-0.364^{* *}$

Dry

Weigh

of Roots

0.0296

0.0077

$\begin{array}{lll}-0.012 & -0.0124 & 0.012\end{array}$

$-0.14 \mid$

0.28

0.067

$-0.095$

$-0.077-0.03$ I

Fresh

Weight

of Bulb

0.061

$-0.051$

0.059

$-0.02$

0.0134

$-0.052 \quad 0.038$

$-0.663 \quad I .544$

$-0.979$

$-0.097$

(g)

Dry

weight of

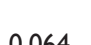

-0.07 I

0.064

$-0.021 \quad 0.015$

$-0.042 \quad 0.012$

$-0.642$

I.59

$-0.960$

$-0.103 \quad-0.091$

Bulb (g)

Diameter

of Bulb

0.053

0.0048

0.056

$-0.026$

$-0.0064 \quad 0.0231$

$-0.560$

1.320

$-1.159$

$-0.064-0.343^{*}$

(cm)

No. of

cloves

0.0176

$-0.037$

$-0.0039$

0.0033

$-0.0055$

0.142

$\begin{array}{ll}-0.0785 & 0.23 \text { I }\end{array}$

$-0.593$

0.270

$\mathbf{0 . 2 7 7} 0.223$

Note: Bold figures indicates the direct effect

Residual Effect $=0.4331$

Citation: Pervin M, Kamrul Hassan Md, Hassan K, et al. Genetic variation of indigenous, improved and exotic allium sativum germplasm. Adv Plants Agric Res. 20I4; I(2):54-60. DOI: I0.I5406/apar.20I4.0I.000II 


\section{Acknowledgements}

None.

\section{Conflict of interest}

The author declares no conflict of interest.

\section{References}

1. Jones HA, Mann LK. Onions and their allies. London: Leonard Hill (Book) Limited; 1963. 286 p.

2. Rahim MA, Fordham R. The advancement of bulbing in garlic with specific reference to late season production in Bangladesh. Acta Hort. 1989;267:271-272.

3. Virk PS, Pooni HS, Syed NH, et al. Fast and reliable genotype validation using microsatellite markers in Arabidopsis thaliana. Theoretical and Applied Genetics. 1999;98(3-4):462-464.

4. Bhatt GM. Significance of path co-efficient analysis determining the nature of character association. Euphytica. 1973;22(2):338-343.

5. Dewey DW, Lu KH. Correlation and path co-efficient analysis of componenets of crested wheat grass and production. Agron J. 1959;51(9):515518.

6. Singh D, Kumar P, Chaudhary BPS. Genetic diversity for some quantitative characters in barley. Indian J Genet. 1980;40(2):391-395.
7. Griffing B, Lindstorm EW. A study of combining abilities of corn inbreeds having varying proportions of corn belt and non corn belt germplasm. Agron J. 1954;46:545-552.

8. Jain SK, Qualest CO, Bhatt GM, et al. Geographical patterns of phenotypic diversity in a world collection of durum wheats. Crop Sci.1975;15(5):700-704

9. Singh RK, Chaudhary BD. Biometrical methods in quantitative genetic analysis. New Delhi: Kalyani Publications; 1985. p. 102-157.

10. Korzun V, Roder M, Worland AJ, et al. Intrachromosomal mapping of genes for dwarfing (Rht12) and vernalization response (Vrnl) in wheat by using RFLP and microsatellite markers. Plant Breeding. 1997;116(3):227-232.

11. Islam MS, Sen K, Rahim K. Estimation of optimum sample size and number of replications in RCBD with unequal observation per cell. Dhaka University Journal of Science. 2000;48(1):89-94.

12. Maaß HI, Klass M. Intraspecific differentiation of garlic (Allium sativum L.) by isozyme and RAPD markers. Theor AppI Genet. 1995;91(1):8997.

13. Ghaderi A, Adams MW, Nassib AM. Relationship between genetic distance and heterosis for yield and morphological traits in dry edible bean and faba bean. Crop Sci. 1984;24:37-24. 